Jurnal Konstruksi Hukum | ISSN: XXXX | E-ISSN: XXXX Vol. 1, No. 1, September 2020 Hal. 68-72| Available online at https://www.ejournal.warmadewa.ac.id/index.php/jukonhum DOI: https://doi.org/10.22225/jkh.1.1.2131.68-72

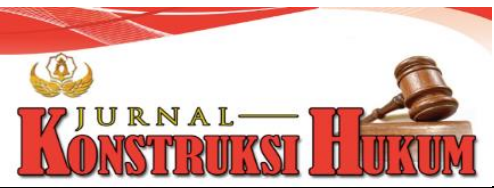

\title{
SANKSI HUKUM TERHADAP PELANGGARAN HAK CIPTA YANG DILAKUKAN OLEH PERUSAHAAN KARAOKE
}

\author{
Bayu Kusuma Permana Putra, I Nyoman Putu Budiartha, I Ketut Sukadana \\ Fakultas Hukum Universitas Warmadewa, Denpasar-Bali, Indonesia
}

\begin{abstract}
Abstrak
Perlindungan hak cipta terutama untuk pembuatan musik atau lagu adalah masalah serius sebab banyak sekali terjadi bajakan musik atau lagu di Indonesia. Royalti harus diberikan kepada orang yang mencipta atau memiliki ciptaannya karena pihak lain menggunakan karyanya untuk diperjualbelikan. Namun terkadang pengusahapengusaha yang menggunakan karya milik orang lain dalam usahanya tidak melakukan atau lalai dalam pembayaran royalti yang dapat menimbulkan kerugian kepada pemegang hak cipta. Tujuan penelitian ini yaitu untuk mengetahui pengaturan royalti atas pemegang hak cipta lagu dalam perusahaan karaoke dan mengetahui sanksi hukum terhadap perusahaan karaoke yang tidak memberikan royalti kepada pemegang hak cipta. Penelitian ini merupakan penelitian hukum normatif dengan pendekatan perundang-undangan, dan pendekatan kasus. Jenis data yang digunakan bersumber dari bahan hukum primer dan bahan hukum sekunder kemudian dianalisis dengan logika deduktif-deduktif. Hasil penelitian menunjukan bahwa didalam Undang-undang Nomor RI Nomor 28 Tahun 2014 Tentang Hak Cipta Setiap orang yang dengan tanpa hak dan atau tanpa izin pencipta atau pemegang hak cipta melakukan pelanggaran hak ekonomi pencipta sebagaimana dimaksud dalam Pasal 9 ayat (1) huruf a, huruf b, huruf e, dan atau huruf g untuk Penggunaan Secara Komersil dipidana dengan pidana penjara paling lama 4 (empat) tahun dan atau pidana denda paling banyak Rp. 1000.000.000,00 (Satu Miliar Rupiah).
\end{abstract}

Kata kunci: Perlindungan hokum; Hak cipta; Royalti

\begin{abstract}
Copyright protection, especially for making music or songs, is a serious problem because there are so many pirated music or songs in Indonesia. Royalties must be given to the person who creates or owns the work because other parties use the work for sale. However, sometimes entrepreneurs who use the work of other people in their business do not make or are negligent in paying royalties which can cause harm to the copyright holder. The purpose of this study is to determine the royalty arrangements for song copyright holders in karaoke companies and to find out legal sanctions against karaoke companies that do not provide royalties to copyright holders. This research is a normative legal research with a statutory approach and a case approach. The type of data used comes from primary legal materials and secondary legal materials then analyzed by deductivedeductive logic. The results of the research show that in Law Number 28 of 2014 concerning Copyright Everyone who without rights and or without the author's permission or copyright holder violates the creator's economic rights as referred to in Article 9 paragraph (1) letter a, letter b, letter $e$, and / or letter $g$ for Commercial Use, shall be punished with imprisonment of up to 4 (four) years and / or a maximum fine of Rp. 1000,000,000.00 (One Billion Rupiah).
\end{abstract}

Keywords: Legal protection; Copyrigh; Royalties

\section{PENDAHULUAN}

Seiring dengan peningkatan laju pembangunan di Indonesia yang diikuti oleh laju perkembangan teknologi, ada juga peningkatan kebutuhan manusia akan gaya hidup. Salah satunya adalah minat publik yang lebih besar di bidang hiburan, terutama apresiasi yang lebih besar dari orang Indonesia dalam musik. Oleh karena itu, semakin banyak orang yang menghargai jiwa artistik mereka sebagaimana diuraikan dalam bentuk penciptaan lagu. Perkembangan musik di Indonesia saat ini semakin besar. Pencinta musik Indonesia tidak kurang menghargai perkembangan musik Indonesia dengan perkembangan musik di Indonesia. Sesuai dengan isi Undang-undang Nomor 28 Tahun 2014 tentang Hak Cipta, seorang penulis lagu memiliki hak eksklusif untuk mengumumkan atau memperluas lisensi kepada pihak lain (Damian, 2002). 
Perkembangan teknologi dan hasil produksi dapat dipatenkan berdasarkan paten. Berdasarkan perundangan yang berlaku pada penulis lagu melekat hak ekonomi, dia bisa memberi pengumuman atau meluaskan izin pada pihak lain untuk memakai hak itu, sehingga orang lain yang punya keinginan karya cipta orang lain untuk digunakan, dia lebih dahulu diwajibkan minta izin pada yang punya lagu atau pemegang hak cipta lagu tersebut.

Dengan memiliki hak eksklusif, orang yang memegang hak cipta lagu bisa melimpahkan ijin yang dimiliki pada orang lain untuk memakai lagu ciptannya tersebut yang lazim disebut lisensi seperti diatur dalam perundangan. Apabila ada pemberian lisensi, secara otomatis akan diikuti dengan bayaran royalti pemegang hak cipta lagu. Royalti artinya balas jasa atas penggunaan hak ekonomi hak cipta berkaitan dengan yang diterima oleh pencipta atau pemilik hak tersebut.

Dengan adanya Undang-undang ini banyak keuntungan yang dapat diperoleh oleh setiap orang atas karya yang ia ciptakan, dimana setiap orang bebas untuk membuat karyanya dengan sebaikbaiknya agar dapat dipertanggungjawabkan kepada orang-orang yang akan menikmati karyanya. Dengan meningkatnya kebutuhan masyarakat dalam dunia permusikan, menyebabkan hak cipta lagu ataupun musik akhir-akhir ini mendaptkan banyak sorotoan. Dimana di era globalisasi ini banyak di temui berbagai macam usaha yang memanfaatkan hasil karya dan ciptaan dari masyarakat yang telah memiliki hak cipta untuk meraih keuntungan, khususnya dalam hal ini banyak para pengusaha yang mendirikan usaha dalam bentuk usaha karaoke yang saat ini menjadi tren dalam masyarakat. Tempat karaoke tersebut menjadi tempat bagi setiap individu atau kelompok untuk dapat bernyanyi di dalam sebuah ruangan, yang digunakan untuk bernyanyi, selain menyediakan tempat bernyanyi tempat karaoke tersebut juga menyediakan berbagai macam makanan dan minuman untuk para pengunjung.

Berdasarkan undang-undang Hak Cipta sebelum memutar lagu kepada orang lain dengan tujuan komersil atau mencari keuntungan haruslah dituangkan dalam betuk perjanjian dengan imbalan sejumlah uang (royalti) kepada pemilik atau pemegang hak ciptanya. Lembaga manajemen kolektor yang ada di indonesia adalah Yayasan Karya Cipta Indonesia, merupakan perantara dan memegang peranan penting bagi pencipta maupun penggunanya. Lembaga ini bertugas menjadi jembatan penghubung hak cipta dengan pemakai sehingga pencipta dapat menerima haknya dengan pasti. Institusi ini juga bertugas bernegosiasi atas besarnya royalti dan persyaratan pengguna karya cipta pada pemakai, menerbitkan lisensi untuk pemakai serta mendistribusikan royalti tersebut.

Menurut Adisumarto (1990), pencipta mempunyai hak untuk mengontrol masyarakat dalam mengumumkan atau memperbanyak ciptaannya, dilain pihak warga masyarakat dapat menggunakan ciptaan secara resmi dan menghindari peredaran barang bajakan, sedangkan Negara kepentingannya dapat menjaga kelancaran dan keamanan masyarakat dibidang ciptaan. Berdasarkan latarbelakang di atas, maka penelitian baru ini bertujuan untuk mengetahui bagaimana pengaturan royalti atas pemegang hak cipta lagu dalam perusahaan karaoke dan mengetahui bagaimana sanksi hukum terhadap perusahaan karaoke yang tidak memberikan royalti

\section{METODE PENELITIAN}

Dalam penyusunan proposal ini menggunakan metode penulisan hukum normatif dengan pendekatan masalah yang dipergunakan melalui peraturan Perundang-undangan. Penelitian normatif yaitu penelitian hukum yang di lakukan dengan cara meneliti bahan pustaka (Soekanto \& Mamudji, 2003). Sumber bahan hukum merupakan tempat di mana diperoleh suatu sumber bahan hukum yang dalam penelitian ini adalah sumber bahan hukum sekunder yaitu tempat kedua di perolehnya bahan hukum. Teknik pengumpulan bahan hukum dilakukan dengan membaca atau mempelajari buku- buku Peraturan Perundang-Undangan serta literatur lainnya yang berkaitan dengan permasalahn yang penulis bahas, penulis menganalisis bahan hukum dengan cara mengumpulkan bahan hukum dan diedit terlebih dahulu dan selanjutnya di manfaatkan sebagai bahan yang bersifat kualitatif.

\section{HASIL DAN PEMBAHASAN}

Hak cipta terdiri dari beberapa macam, yaitu berupa buku, lagu atau musik, arsitektur, fotografi dan sinematografi. Lagu atau musik merupakan satu diantaranya. Hasil produksi lagu dan musik banyak memberikan sumbangan bagi Indonesia dalam meningkatkan perekonomian. Lagu bisa dinikmati oleh kalangan masyarakat selain itu menikmati musik bisa dilakukan dengan mudah yaitu cukup didengarkan saja. Lagu bisa menghibur manusia. Megawati pada saat menjabat presiden menyatakan tanggal 10 Maret menjadi hari musik nasional (Nainggolan, 2011). Pemerintah memprioritaskan untuk 
melindungi hak cipta utamanya karya lagu. Itu disebabkan di Indonesia banyak sekali ditemukan lagu bajakan.

Pemilik lagu atau pencipta lagu berhak mendapatkan royalti dengan membayar penggunaan manfaat suatu ciptaan yang diperjualbelikan. Jumlah royalti disepakati dengan mengadakan kesepakatan lisensi. Disini ada pihak yang menerima dan memberi lisensi. Sesuai perjanjian, pihak yang menerima lisensi bisa memanfaatkan hak cipta untuk dijual dengan membayar royalti pada yang memberi lisensi. Diera sekarang pemungut royalti dilakukan oleh LMK, banyak sebutan yang digunakan antara lain CMO, PRS dan CS. Pembentukan lembaga untuk agar bisa membantu pencipta dan hak cipta mengawasi dan mengumpulkan imbalan atas pengunana lagu atau musik berupa lagu atau musik. Lembaga lainnya melaksanakan tugas menyiapkan administrasi hak atas penggunaan hak ekonomi dan royalti dikumpulkan dan langsung disalurkan pada pencipta atau pemegang hak cipta.

Dalam pasal 1 ayat 22 Undang-undang Hak Cipta No. 28 Tahun 2014: Institusi Manajemen Kolektif ialah institusi dalam bentuk badan hukum nirlaba yang diotorisasi oleh Penulis, Pemegang Hak Cipta, dan / atau Pemilik Hak Terkait untuk mengelola hak ekonominya dalam bentuk mengumpulkan dan menyalurkan royalti.

Kehadiran LMK diharapkan mampu mengatur selanjutnya distribusi royalti dan jumlah nya, pemegang hak cipta dan pemilik hak terkait. Meski begitu, yang harus diklarifikasi adalah pemberian jumlah royalti yang harus dibayar. Pasal 1 ayat 24 undang-undang Hak Cipta 2014 yang berbunyi Penggunaan secara komersil adalah pemanfaatan Ciptaan dan/ atau produk Hak Terkait dengan tujuan untuk memperoleh keuntungan ekonomi dari berbagai sumber atau berbayar.

Dengan adanya LMKN maka setiap pengusaha karaoke dapat membayar royalti terhadap pemegang hak cipta Kemudian LMKN memberikan lisensi kepada pengguna dalam hal ini adalah yang punya tempat karaoke, atas permintaan manajer karaoke untuk tujuan komersial. Sistem lisensinya dengan memutar atau memainkan seluruh repertoire yang dikelola LMKN dengan pembayaran royalti di depan. Dari pemeberian lisensi itu tempat karaoke akan di manfaatkan untuk mencari keuntungan, dari keuntungan itulah adalah hak dari pencipta lagu pemegang hak, kemudian pengelola tempat karaoke membuat laporan tentang lagu-lagu apa saja yang diperdengarkan (Widjaja, 2001). Setelah LMKN menerima laporan dari pengelola tempat karaoke, kemudian LMKN pelaporan itu akan diolah secara cermat dan tepat untuk menentukan jumlah royalti yang selanjutnya didistribusikan ke masing-masing pencipta lagu atau pemegang hak. Undang-undang royalti ialah bayaran yang diterima pemegang hak oleh orang yang memakai hak tersebut berkaitan atas perizinan pengeksploitasian ciptaan hak tersebut (Isnaini, 2009).

Besaran imbalan itu kata sepakat kedua belah pihak sesuai ukuran dan selanjutnya dicantumkan berbentuk perjanjian berbentuk tulisan atau akta. Menurut Muhammad (2010), perlindungan hukum yaitu langkah yang ditentukan perundangan untuk meminimalisir kejadian pelanggaran hak (Ramli, 2000), sedangkan menurut (Hadjon, 1987), perlindungan hukum adalah suatu kondisi subyektif yang menyatakan bahwa harus ada sejumlah subjek hukum untuk segera mendapatkan sejumlah sumber daya, dalam rangka mempertahankan keberadaan subjek hukum yang dijamin dan dilindungi oleh hukum, sehingga kekuatan mereka diatur dalam proses membuat keputusan politik dan ekonomi, terutama dalam distribusi sumber daya pada tingkat individu atau structural.

Pendaftaran ciptaan dilakukan di Direktorat Jenderal Hak Kekayaan Intelektual Departemen Kementrian Hukum dan Hak Asasi Manusia Republik Indonesia. Dengan melakukan pendaftaran tersebut para petugas akan mencatat nama, alamat dan judul Ciptaan yang bersangkutan di dalam daftar umum ciptaan yang diadakan khusus untuk itu. Percatatan dilakukan pada Daftar Umum Ciptaan dan pengumuman resminya dilakukan Tambahan Berita Negara (Hadjon, 1987).

Masalah penting dihadapi berkenaan dengan waktu perlindungan hukum apalagi berhubungan dengan permasalahan hak cipta yang mempunyai sifat lintas batas, contohnya di Jerman, yang melindungi hak cipta terus menerus seumur hidupnya kepada penulis ditambah 70 tahun, Indonesia hanya menambahkan 50 tahun. Jika prinsip perlakuan nasional diterapkan, Jerman harus melindungi ciptaan Indonesia di Jerman pada periode yang sama dengan warganya, yaitu seumur hidup ditambah 70 tahun. Sementara, jika saling perlakuan diterapkan, karya yang sama dan Pencipta Indonesia di Jerman dilindungi seumur hidup, penulis ditambah 50 tahun, sebagai periode perlindungan yang ditawarkan oleh Indonesia.

Perbedaan dalam periode perlindungan terkait pengkategorian Pencipta terjadi permasalahan serius. Di Inggris, misalnya, produsen sinematografi dianggap sebagai produsen, sementara di 
Perancis produsen adalah pihak yang dilindungi berdasarkan hak cipta karena mereka hanya penulis bersama. Di Britania Raya, produser dilindungi untuk masa pakai tambahan 70 tahun, sementara di Prancis hanya 70 tahun yang dilindungi untuk produksi film yang sama. Selain itu, ditetapkan bahwa negara memiliki hak cipta untuk seni dan budaya yang berlaku untuk jangka waktu yang tidak terbatas (Pasal 31 Undang- undang 19 Tahun 2002). Adanya periode perlindungan hak cipta antara negara yang berbeda, klausa grandfather secara teoritis dikenal sebagai jaminan, yaitu, ketika Pencipta meninggal dan menerima hak seumur hidup ditambah 70 tahun setelah kematian, dan ahli waris ini tidak dapat dipersingkat.

Mengingat adanya perbedaan jangka waktu perlindungan Hak Cipta di antara negara-negara, secara teoretis dikenal grandfather clause sebagai pengaman, yakni manakala Pencipta sudah meninggal dan kepadanya telah diberikan hak seumur hidup ditambah 70 tahun setelah meninggal, maka untuk kepentingan ahli warisnya jangka waktu ini tidak dapat diperpendek (Jened, 2014).

Karya yang sama yang dimiliki oleh 2 orang atau lebih berlaku untuk kehidupan Sang Pencipta yang mati pada akhirnya dan berlangsung hingga 50 tahun sesudahnya (Pasal 30). Hak cipta untuk karya-karya yang diumumkan bagian demi bagian dihitung melalui tanggal pengumuman yang terakhir terdiri dari 2 volume atau lebih, serta ringkasan dan berita yang diumumkan secara berkala dan bukan pada waktu yang sama, setiap volume atau ringkasan berita tersebut masing-masing dianggap karya terdiri dari (Pasal 32 Undang-undang 19 tahun 2002 tentang Hak Cipta).

Penegakan hukum adalah upaya untuk membuat ide keadilan, kepastian hukum dan manfaat sosial terwujud nyata. Sehingga penegakan hukum pada dasarnya adalah proses mewujudkan ide. Penegakan hukum adalah penegakan fungsi atau fungsi aktual norma-norma hukum sebagai pedoman bagi para pelaku dalam lalu lintas atau hubungan hukum dalam kehidupan masyarakat dan negara. Penegakan hukum merupakan upaya mewujudkan gagasan dan konsep hukum yang diharapkan oleh masyarakat untuk menjadi nyata. Banyak hal yang terlibat dalam menegakkan hukum (Dellyana, 1988).

Undang-undang material tertentu tidak akan berjalan seefektif yang diharapkan jika tidak dilengkapi dengan aturan formal untuk menegakkan hukum materi dalam kehidupan sehari-hari. Penegakan hak cipta tidak dimaksudkan untuk mencapai cita-cita hukum hak cipta, dengan kata lain, ini dimaksudkan untuk mencapai tujuan perlindungan hak cipta itu sendiri. Kerugian ini adalah hasil dari pelanggaran hak cipta. Pihak-pihak yang berisiko kalah akibat pelanggaran ini meliputi:

1. Pencipta dan pelaku karena tidak mendapat pembayaran sejumlah uang yang seharusnya mereka peroleh.

2. Penerbit dan produser rekaman karena tidak mendapatkan investasi finansial dan keahlian yang telah mereka tanam.

3. Penjual dan distributar karena tidak bersaing secara sehat dengan pihak lain yang melakukan pelanggaran (Fahmi, 2019).

Penegakan hukum sebagai akibat dari pelanggaran hak cipta dapat ditempuh melalui dua saluran, yaitu jalur layanan sipil dengan mengajukan proses perdata dan proses pidana dengan penuntutan pidana pelanggaran hukum yang diajukan oleh hukum perdata (kompensasi, dll) masih dapat diajukan ke hukum pidana, dan lebih disukai juga dalam hak cipta.

Terkait dengan hak cipta tidak membayar royalti berdasarkan hasil wawancara di kantor wilayah kementrian hukum dan HAM Provinsi Bali. Hak cipta adalah hak khusus penulis, yang secara otomatis muncul berdasarkan prinsip deklaratif setelah sebuah karya diwujudnyatakan tanpa pengurangan batasan menurut ketentuan yang berlaku. Hak ini, hanya hak yang dicadangkan bagi Pencipta, sehingga tidak ada pihak lain yang dapat menggunakan hak-hak ini tanpa izin penulis. Pemegang hak cipta yang bukan pencipta hanya memiliki bagian dari hak eksklusif dalam bentuk hak ekonomi. Sehingga apabila terdapat perusahaan/ perorangan yang melakukan pelanggaran Hak Cipta harus mendapatkan sanksi yang tegas, akan tetapi Undang-undang Kekayaan Intelektual sekarang adalah berupa Delik Aduan (pasal 120 Undang-undang No 28 Tahun 2014 tentang hak cipta) sehingga diperlukan peran aktif pemilik hak cipta untuk dapat melaporkan adanya pelanggaran yang ada. Undang-undang No. 28 tahun 2014 tentang hak cipta yang diuraikan pada pada BAB XVII Ketentuan Pidana sudah sangat jelas mengenai pelanggaran dan sanksi yang diberikan kepada pelanggar hak cipta. Pasal tersebut dengan jelas telah mencantumkan ancaman hukuman penjara hingga sepuluh tahun serta denda hingga empat miliar rupiah. Demikian hasil wawancara terhadap Ibu Putu Witari selaku kepala Sub Bidang Kekayaan Intelektual pada tanggal 18 November 2019. 


\section{SIMPULAN}

Berdasarkan hasil analisis di atas, maka dapat disimpulkan bahwa pengaturan royalti pemegang Hak Cipta atas lagu dalam usaha karaoke telah dicantumkan dalam Undang-Undang Hak Cipta No. 28 Tahun 2014. Dimana bagi setiap pengusaha yang ingin menggunakan karya milik orang lain untuk usahanya diharuskan memiliki lisensi (Izin tertulis) dari pihak pencipta untuk melaksanakan hak ekonomi atas ciptaannya. Untuk mendapatkan lisensi pengusaha harus mendaftarkan terlebih dahulu usahanya di lembaga manajemen kolektif (LMK), dimana manajemen ini merupakan lembaga yang mengatur besar kecilnya tarif royalti atas ciptaan atau produk hak terkait tersebut untuk kepentingan komersil. Kemudian, sanksi hukum yang diberikan kepada pelaku usaha yang tidak melakukan pembayaran terhadap royalti terhadap pemegang hak cipta. Pengusaha karaoke akan dikenakan sanksi perdata dan pidana berupa ganti rugi dan penghentian penggunaan bagi usaha karaoke, serta sanksi hukuman penjara sebagaimana telah diatur dalam Undang-undang Hak Cipta No. 19 Tahun 2002 maupun Undang-undang Hak Cipta No. 28 Tahun 2014.

\section{DAFTAR PUSTAKA}

Adisumarto, H. (1990). Hak Milik Intelektual Khususnya Hak Cipta. Jakarta: Akademika Presindo. Damian, E. (2002). Hukum Hak Cipta. Bandung: P.T. Alumni Bandung.

Dellyana, S. (1988). Konsep Penegakan Hukum. Yogyakarta: Liberty.

Fahmi, K. (2019). Perlindungan Hukum Terhadap Karya Cipta Lagu "Hilang" Atas Tindakan Perbanyakan Atas Karya Cipta Tanpa Perjanjian Lisensi (Studi Putusan Mahkamah Agung Republik Indonesia Nomor 192 PK/Pdt.Sus/2010). Jurnal Hukum Kaidah: Media Komunikasi Dan Informasi Hukum Dan Masyarakat, 19(1), 94-113.

Hadjon, P. M. (1987). Perlindungan Hukum Bagi Rakyat Indonesia. Surabaya: PT. Bina Ilmu.

Isnaini, Y. (2009). Hak Cipta dan Tantangannya di Era Cyber Space. Bogor: Ghalia Indonesia.

Jened, R. (2014). Hukum Hak Cipta (Copyright's Law). Jakarta: Citra Aditya Bakti.

Muhammad, A. (2010). Hukum Perjanjian. Bandung: PT Alumni.

Nainggolan, B. (2011). Pemberdayaan Hukum Hak Cipta Dan Lembaga Manajemen Kolektif (I). Bandung: PT. Alumni.

Ramli, A. M. (2000). H.A.K.I Hak Atas Kepemilikan Intelektual, Teori Dasar Perlindungan Rahasia Dagang. Bandung: Mandar Maju.

Soekanto, S., \& Mamudji, S. (2003). Penelitian Hukum Normatif: Suatu Tinjauan Singkat. Jakarta: PT. RajaGrafindo Persada.

Widjaja, G. (2001). Seri Hukum Bisnis Lisensi. Jakarta: PT. Raja Grafindo Persada. 